\title{
Article \\ Ovicidal and Physiological Effects of Essential Oils Extracted from Six Medicinal Plants on the Elm Leaf Beetle, Xanthogaleruca luteola (Mull.)
}

\author{
Bita Valizadeh ${ }^{1}$, Jalal Jalali Sendi ${ }^{2}{ }^{\circledR}$, Marziyeh Oftadeh ${ }^{2}$, Asgar Ebadollahi ${ }^{3, *(1)}$ \\ and Patcharin Krutmuang $4,5, *$ (D) \\ 1 Department of Plant Protection, Faculty of Agriculture, Shahid Bahonar University of Kerman, \\ Kerman 7616913439, Iran; bita.valizade@gmail.com \\ 2 Department of Plant Protection, Faculty of Agricultural Sciences, University of Guilan, Rasht 416351314, Iran; \\ jjalali@guilan.ac.ir (J.J.S.); marziye.oftade@gmail.com (M.O.) \\ 3 Department of Plant Sciences, Moghan College of Agriculture and Natural Resources, \\ University of Mohaghegh Ardabili, Ardabil 5697194781, Iran \\ 4 Innovative Agriculture Research Center, Faculty of Agriculture, Chiang Mai University, \\ Chiang Mai 50200, Thailand \\ 5 Department of Entomology and Plant Pathology, Faculty of Agriculture, Chiang Mai University, \\ Chiang Mai 50200, Thailand \\ * Correspondence: ebadollahi@uma.ac.ir (A.E.); patcharink26@gmail.com (P.K.)
}

\section{check for} updates

Citation: Valizadeh, B.; Jalali Sendi, J.; Oftadeh, M.; Ebadollahi, A.; Krutmuang, P. Ovicidal and Physiological Effects of Essential Oils Extracted from Six Medicinal Plants on the Elm Leaf Beetle, Xanthogaleruca luteola (Mull.). Agronomy 2021, 11, 2015. https://doi.org/10.3390/ agronomy11102015

Academic Editors: Zhiqiang Kong and Ran Wang

Received: 8 August 2021

Accepted: 2 September 2021

Published: 7 October 2021

Publisher's Note: MDPI stays neutral with regard to jurisdictional claims in published maps and institutional affiliations.

Copyright: (c) 2021 by the authors. Licensee MDPI, Basel, Switzerland. This article is an open access article distributed under the terms and conditions of the Creative Commons Attribution (CC BY) license (https:/ / creativecommons.org/licenses/by/ $4.0 /)$.

\begin{abstract}
Plant essential oils may serve as safe alternatives to detrimental synthetic pesticides due to relatively lower side effects on the environment and non-targeted organisms. The current study was conducted to investigate the ovicidal toxicity and physiological disruptions of six medicinal plant essential oils, including Artemisia annua L., Lavandula angustifolia Mill., Origanum vulgare L., Rosmarinus officinalis Spenn., Satureja hortensis L., and Thymus vulgaris L., on elm leaf beetle Xanthogaleruca luteola (Mull.). The $\mathrm{LC}_{50}$ (Lethal Concentration to kill 50\% of tested insects) values of 122.8, 287.5, 152.8, 180.6, 315.9, and $1366.2 \mathrm{ppm}$ were recorded for T. vulgaris, L. angustifolia, A. annua, S. hortensis, R. officinalis, and O. vulgare, respectively, $72 \mathrm{~h}$ after treatment of 3-day-old eggs of the pest. Significant decreases in the amounts of glucose, protein, and triglyceride macromolecules were also observed after treatment. The application of essential oils derived from T. vulgaris, A. annua, and S. hortensis at $400 \mathrm{ppm}$ revealed $100 \%$ ovicidal activity. Accordingly, tested essential oils, particularly the essential oil of T. vulgaris, have been promising potential as biorational insecticides in the management of X. luteola.
\end{abstract}

Keywords: biorational pesticides; elm leaf beetle; essential oils; macromolecules; ovicidal toxicity

\section{Introduction}

The elm leaf beetle, Xanthogaleruca luteola Müller (Coleoptera: Chrysomelidae), is a defoliating pest of elm trees (Ulmus spp.) widely distributed in Europe, North Africa, Asia, Australia, and temperate areas in North and South America [1]. Elm leaf beetle adults hibernate overwinter in bark fissures and woodpiles and emerge in spring to feed on elm foliage for 1-2 weeks before commencement of egg-laying. Adults feed through leaves, more often in a shot hole pattern. The eggs of elm leaf beetle are bright yellow and laid in clusters, averaging 14-20 eggs per cluster, that are mainly located on the underside of a leaf. Both larvae and adults of X. luteola feed on the emergent leaves. The larvae of the elm leaf beetle can feed on elm leaves for 2-4 weeks, undergo three instars, and cause more damage than adults by skeletonizing the leaf surface [2]. Severe infestations by elm leaf beetle larvae can cause physiological stress, defoliation of trees, and enhance the susceptibility of host plants to other pests and diseases [3]. Since elm trees are widely planted in cities and suburbs, the excessive use of chemical pesticides to protect them from the population 
impact of X. luteola leads to municipal environment pollution, interruption of ecological balance, the mortality of non-target organisms, development of insecticide resistance, as well as toxic waste [3,4].

Natural products derived from plants are potential biorational alternatives to synthetic insecticides for controlling insect infestations. In this regard, botanical insecticides, consisting of naturally occurring chemicals from plant species, are widely studied $[5,6]$. These compounds comprise a variety of secondary metabolites, including phenols, alkaloids, and terpenoids, and show significant toxicity against insect pests $[7,8]$. Among botanical compounds, essential oils (EOs), known as volatile secondary metabolites derived from seeds, roots, leaves, and fruits of plants, are low-risk pesticides that showed lethal and sublethal effects on several insect pests [9-11]. Indeed, they have a broad-spectrum of deteriorative effects against insect pests, including acute toxicity [12], antifeedant [13], repellent [14], oviposition deterrent [15], growth regulators [16], and anti-vector [17], activities. As plant EOs have short environmental persistence, they are considered biodegradable agents in the environment [18]. Furthermore, plant EOs have multiple neurotoxic impacts on insects via different mechanisms, including gamma-aminobutyric acid, octopamine synapses, and inhibition of acetylcholinesterase, and accordingly, the chance of insect pests to resistance before them may be very low [19].

Recent studies have explored the insecticidal effect of EOs derived from T. vulgaris, L. angustifolia, and Schinus molle L. on larval and adult stages of X. luteola [20], but there has been no attempt to explore the toxicity of EOs on X. luteola at the egg stage. It has been reported that oil-based insecticides, such as plant essential oils, penetrate the insect eggshell more readily than water-based insecticides [21]. The ovicidal effect of T. vulgaris, L. angustifolia, A. annua, S. hortensis, R. officinalis, and O. vulgare EOs on silver leaf whitefly (Bemisia tabaci Gennadius), common green bottle fly (Lucilia sericata Meigen), Angoumois grain moth (Sitotroga cerealella Olivier), carob moth (Ectomyelois ceratoniae Zeller), and bean weevil (Acanthoscelides obtectus Say) have been studied [22-24].

Plant EOs can inhibit the growth and metabolism of insects through physiological processes and enzymatic activities and can have mortal influences on insects by feeding and oviposition deterrence $[25,26]$. Reduction and disruption in the amounts of biochemical components in the treated larvae with EOs were described in some studies $[13,27]$.

Investigating the biochemical effects of EOs on insects, in addition to their ovicidal effects, can provide a foundation for improving the efficacy of pesticides and efficient pest management. Accordingly, the current study was aimed to assess potential toxicity and ovicidal or egg-hatching inhibition by T. vulgaris, L. angustifolia, A. annua, S. hortensis, $R$. officinalis, and O. vulgare EOs on X. luteola. To gain a better understanding of the physiological interactions between EOs and the X. luteola eggs, the metabolic responses of eggs after exposure to different concentrations of EOs were also explored by measuring the amounts of storage macromolecules glucose, protein, and triglyceride.

\section{Materials and Methods}

\subsection{Mass Rearing of Insects}

Adults of X. luteola were collected from elm trees (Ulmus densa Litw) cultivated in Rasht $\left(37^{\circ} 16^{\prime} 51^{\prime \prime} \mathrm{N} 49^{\circ} 34^{\prime} 59^{\prime \prime} \mathrm{E}\right)$, Iran, and were maintained in a rearing chamber at $25 \pm 1^{\circ} \mathrm{C}$, $75 \pm 5 \%$ relative humidity and 16: $8 \mathrm{~h}$ (light: dark) photoperiod. The adults were sexed and fed on elm leaves; their eggs were used to maintain the culture and placed in plastic jars $10 \times 20 \mathrm{~cm}$ for bioassay.

\subsection{Extraction of Essential Oils}

Six different types of aromatic plants, taxonomically related to the Lamiaceae and Asteraceae family, were collected from different growing locations in Iran (Table 1). The aerial parts of plants were dried in the shade. The dried flowers were made into a fine powder by a grinder (354, Moulinex, Paris, France). Essential oils were extracted based on the method described by British Pharmacopoeia [28]. Briefly, $50 \mathrm{~g}$ of dried herb powder 
was mixed with $1000 \mathrm{~mL}$ distilled water and kept for $24 \mathrm{~h}$. Samples were subjected to $2 \mathrm{~h}$ hydrodistillation in a Clevenger-type apparatus. This process was repeated several times to receive the required amount of aqueous/oil distillate (about $3 \mathrm{~mL}$ ). The oil phase was isolated from the obtained solution by dehydration over anhydrous sodium sulfate $\left(\mathrm{Na}_{2} \mathrm{SO}_{4}\right)$ (Merck Co., Darmstadt, Germany). Extracted essential oils were stored in standing $1.5 \mathrm{~mL}$ microtubes covered with aluminum foil and kept at $4{ }^{\circ} \mathrm{C}$.

Table 1. List of plants used for exploring the ovicidal effect of their essential oils on elm leaf beetle eggs.

\begin{tabular}{|c|c|c|c|c|c|}
\hline Common Name & Scientific Name & Family & GPS/Location & Part & $\begin{array}{c}\text { Essential Oil Yield } \\
(\%(w / w))\end{array}$ \\
\hline Garden thyme & Thymus vulgaris & Lamiaceae & $37.159592,49.001185$ & Leaves & $1.27 \pm 0.02^{\mathrm{c}}$ \\
\hline Lavender & Lavandula angustifolia & Lamiaceae & $38.419401,48.860797$ & Leaves & $1.61 \pm 0.06^{b}$ \\
\hline Sweet wormwood & Artemisia annua & Asteraceae & $37.198539,49.653243$ & Leaves & $2.90 \pm 0.03^{\mathrm{a}}$ \\
\hline Summer Savoury & Satureja hortensis & Lamiaceae & $35.322589,51.625637$ & Leaves & $2.11 \pm 0.09^{a b}$ \\
\hline Rosemary & Rosmarinus officinalis & Lamiaceae & $37.193775,49.641361$ & Leaves & $1.10 \pm 0.00^{c}$ \\
\hline Oregano & Origanum vulgare & Lamiaceae & $36.949912,50.603010$ & Leaves & $1.72 \pm 0.01^{\mathrm{b}}$ \\
\hline
\end{tabular}

Data are mean \pm SE. Different lowercase letters in the same column indicate significant difference at $p \leq 0.05$ according to Tukey test.

\subsection{Assessment of the Ovicidal Effect of Essential Oils}

To assess the direct ovicidal effect of essential oils on elm leaf beetle eggs, 3-dayold eggs were randomly collected from the mass-reared colonies and exposed to EOs concentrations diluted in distilled water+Tween- 80 by egg dipping method. Experiments were performed with 3 replications; 5 eggs-masses (12-15 eggs) per replication were exposed to EOs for $30 \mathrm{sec}$ and left in Petri dishes $(10 \mathrm{~cm})$ to hatch. Untreated controls were exposed to only distilled water+Tween- 80 for 30 secs. Egg mortality was determined for individual eggs within each egg mass per each treatment using a stereomicroscope. Percent ovicidal activity was assessed after $72 \mathrm{~h}$ exposure to EOs by the following formula [29]:

Ovicidal Percentage $=\frac{\text { Number of eggs hatched in control }- \text { Number of eggs hatched in treatment }}{\text { Number of egg hatched in control }} \times 100$

\subsection{Preparation of Eggs Homogenates for Biochemical Assay}

After $72 \mathrm{~h}$ of treatment of X. luteola eggs with EOs at the concentrations of 100, 200, 300 , and $400 \mathrm{ppm}$, about $10 \mathrm{~g}$ unhatched eggs from each treatment and control groups were weighed and homogenized by a glass pestle in $0.5 \mathrm{~mL}$ of distilled water. The homogenate was centrifuged at $13,000 \times g$ at $4{ }^{\circ} \mathrm{C}$ for $10 \mathrm{~min}$. The homogenized egg supernatant was transferred into a $1.5 \mathrm{~mL}$ Eppendorf ${ }^{\circledR}$ tube and stored at $-20^{\circ} \mathrm{C}$. Biochemical assays were conducted with 3 replicates.

\subsection{Protein Assay}

The protein concentration of the homogenized egg supernatant treated with EOs was determined via Biuret's method [30] using a total protein assay kit (Biochem Co., Tehran, Iran).

\subsection{Determination of Glucose}

Glucose concentration of the homogenized egg supernatant, treated with EOs was determined by automated enzymatic assays using a glucose assay kit (Biochem Co., Tehran, Iran) as described by Siegert [31] with some modifications: reagent $A$ and reagent $B$ were mixed (4:1) followed by addition of samples. Glucose levels were estimated by measuring reduction in absorption at $492 \mathrm{~nm}$ in an ELISA reader (Awareness, Temecula, CA, USA).

\subsection{Determination of Triglyceride}

Triglyceride concentration of the homogenized egg supernatant, treated with EOs, was determined by a triglyceride kit (Biochem Co., Tehran, Iran) according to protocol 
described by Fossati and Prencipe [32]. The reducing absorption rate for triglyceride analysis was read at $545 \mathrm{~nm}$ in an ELISA reader (Awareness, Temecula, CA, USA).

\subsection{Statistical Analysis}

Control mortality was rare, and where corrections for mortality were necessary, these were accomplished using Abbott's formula [33]. Egg mortality and lethal concentrations of EOs were determined $72 \mathrm{~h}$ after treatment, and data were analyzed by POLO-PC software to calculate $\mathrm{LC}_{50}$ values as the effective concentrations to follow the biochemical experiments. Relative potency (RP) for each mixture was determined based on O. vulgare (lowest toxicity) and calculated using the following formula: $\mathrm{RP}=\mathrm{LC}_{50}$ of $O$. vulgare essential oil/LC 50 of individual essential oil. Raw data obtained from the biochemical assay and ovicidal bioassay were subjected to a one-way statistical analysis of variance test (ANOVA) for significant differences in the measured parameters. The Tukey-Kramer test at a $5 \%$ significance level was considered for comparison of means using SAS statistical software.

\section{Results}

\subsection{The Ovicidal Activity of EOs}

The hydrodistillation of aerial parts of T. vulgaris, L. angustifolia, A. annua, S. hortensis, $R$. officinalis, and $O$. vulgare gave yellowish oils with a yield of $1.27 \pm 0.02,1.61 \pm 0.06$, $2.9 \pm 0.03,2.1 \pm 0.09,1.1 \pm 0.00$, and $1.7 \pm 0.01 \%(w / w)$, respectively (Table 1$)$.

Concentration-dependent toxicity was determined for all EOs. Untreated insects in control groups indicated mortality ranging from $5-10 \%$, which were corrected through Abbott formula. All doses of EOs revealed ovicidal activity on X. luteola by the maximum mortality of $100 \pm 00,92.76 \pm 3.17,100 \pm 00,100 \pm 00,74.61 \pm 2.31$, and $21 \pm 4.13 \%$, for T. vulgaris $(\mathrm{F}=1228.34 ; \mathrm{df}=3 ; p<0.0001)$, L. angustifolia $(\mathrm{F}=584.50 ; \mathrm{df}=3 ; p<0.0001)$, A. annua $(\mathrm{F}=988.09 ; \mathrm{df}=3 ; p<0.0001)$, S. hortensis $(\mathrm{F}=1228.34 ; \mathrm{df}=3 ; p<0.0001)$, $R$. officinalis $(\mathrm{F}=1366.28 ; \mathrm{df}=3 ; p<0.0001)$, and $O$. vulgare $(\mathrm{F}=89.14 ; \mathrm{df}=3 ; p<0.0001)$ EOs at the concentration of $400 \mathrm{ppm}$, respectively (Figure 1).

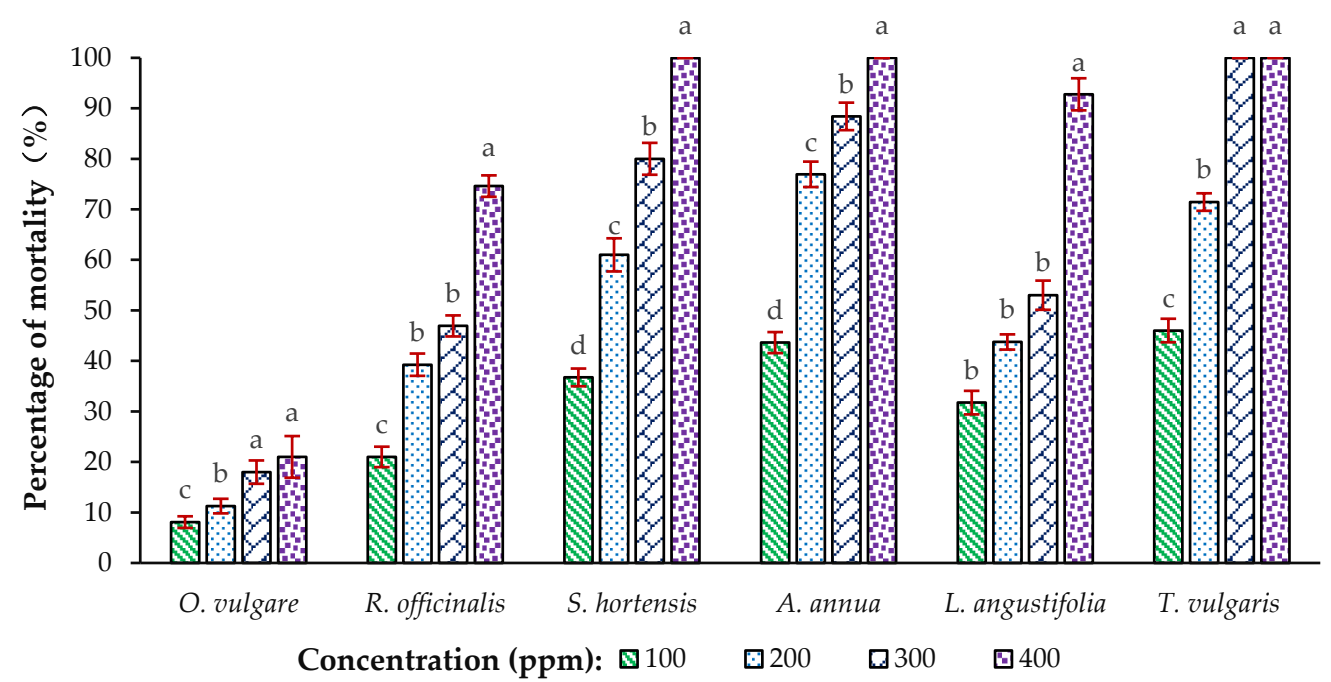

Figure 1. Ovicidal activity of applied essential oils against Xanthogaleruca luteola eggs. Statistical differences are shown by different letters according to Tukey's test at $p \leq 0.05$.

The $\mathrm{LC}_{50}$ values were estimated for each EO. T. vulgaris essentials showed the highest ovicidal toxicity with the lowest $\mathrm{LC}_{50}$ of $122.8 \mathrm{ppm}$, indicating the highest relative potency (Table 2). The $\mathrm{LC}_{50}$ value estimated for $A$. annua $\mathrm{EO}$ was $152.8 \mathrm{ppm}$, which was much lower than the $\mathrm{LC}_{50}$ value of Satureja hortensis EO (180.6 ppm), indicating a better efficacy and ovicidal activity followed by T. vulgaris (Table 2). 
Table 2. Estimated $\mathrm{LC}_{50}$ values and relative potencies of six essential oils on Xanthogaleruca luteola eggs after $72 \mathrm{~h}$ of exposure.

\begin{tabular}{ccccc}
\hline Essential Oil & Slope $\pm \mathbf{S E}$ & $\begin{array}{c}\mathbf{X}^{\mathbf{2}} \\
(d f=3)\end{array}$ & $\begin{array}{c}\text { LC }_{\mathbf{5 0}}(\mathbf{9 5 \%} \mathbf{C I}) \mathbf{a} \\
(\mathbf{p p m})\end{array}$ & $\begin{array}{c}\text { Relative } \\
\text { Potency }^{\mathbf{b}}\end{array}$ \\
\hline Artemisia annua & $1.74 \pm 0.26$ & 4.35 & $152.8(64.24-291.00)$ & 8.94 \\
Lavandula angustifolia & $1.66 \pm 0.28$ & 4.62 & $287.5(99.81-566.01)$ & 4.75 \\
Origanum vulgare & $2.04 \pm 0.34$ & 2.55 & $1366.2(904.03-1094.6)$ & 1.00 \\
Rosmarinus officinalis & $1.70 \pm 0.27$ & 4.15 & $315.9(117.2-578.5)$ & 4.32 \\
Satureja hortensis & $1.31 \pm 0.22$ & 4.20 & $180.6(53.09-409.29)$ & 7.56 \\
Thymus vulgaris & $1.79 \pm 0.293$ & 4.31 & $122.8(56.2-235.0)$ & 11.12 \\
\hline
\end{tabular}

a CI: confidence interval. ${ }^{\mathrm{b}}$ Relative potency $=\mathrm{LC}_{50}$ of $\mathrm{O}$. vulgare essential oil/ $\mathrm{LC}_{50}$ of another essential oil.

\subsection{Total Protein Level in X. luteola Eggs Post-Exposure to EOs}

Total protein eggs treated were significantly decreased compared to control $(\mathrm{F}=27.03$; $\mathrm{df}=5,6 ; p<0.05$ ) (Figure 2).

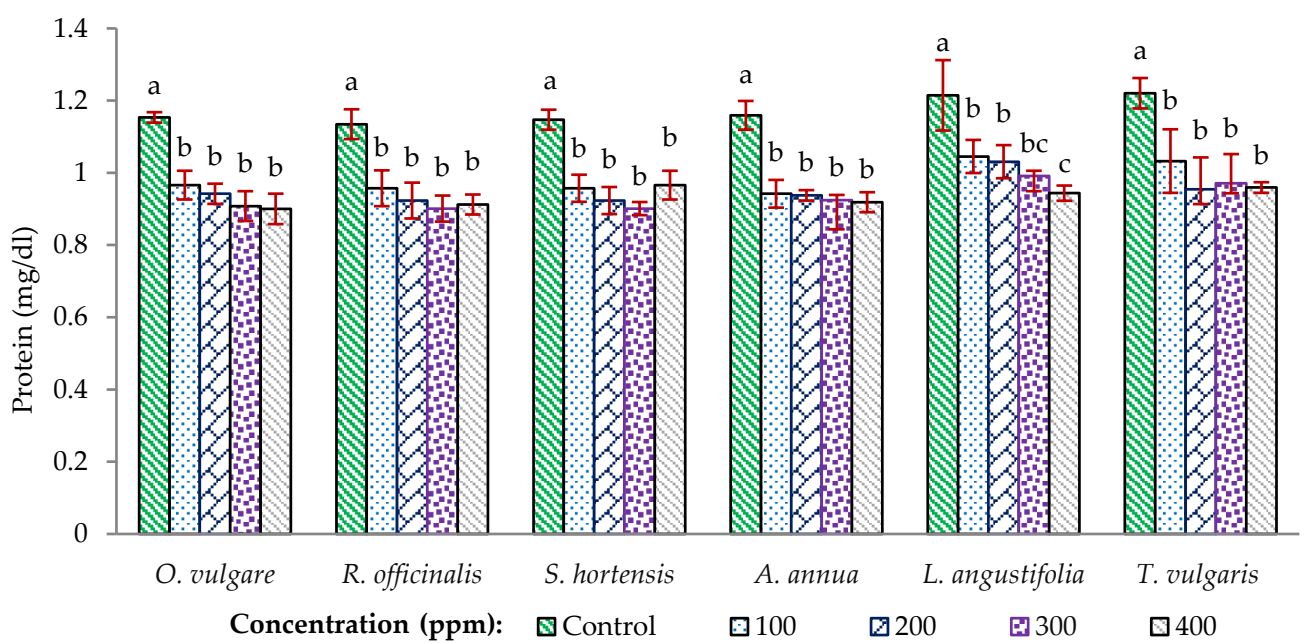

Figure 2. Effect of different concentrations of essential oils on the total protein $(\mathrm{mg} / \mathrm{dL})$ of Xanthogaleruca luteola eggs. Statistical differences are shown by different letters according to Tukey's test at $p \leq 0.05$.

\subsection{Total Glucose of X. luteola Eggs Treated}

Profiling the glucose level in eggs per each treatment revealed a higher impact of O. vulgare in reducing the total glucose content even at its lower concentrations (Figure 3 ) $(\mathrm{F}=15.97 ; \mathrm{df}=5,6 ; p<0.05)$.

\subsection{Total Triglyceride of X. luteola Eggs Treated}

Profiling total triglyceride content of X. luteola eggs after exposing with $A$. annua $\mathrm{EO}$ at $400 \mathrm{ppm}$ revealed higher reductions by significant differences ranging from $1.68 \pm 0.09 \mathrm{mg} / \mathrm{dL}$ to $0.92 \pm 0.05 \mathrm{mg} / \mathrm{dL}$ compared to triglycerides level assessed for control $(\mathrm{F}=31.42 ; \mathrm{df}=5$, 6; $p<0.001$ ) (Figure 4). This is suggesting that the higher concentrations of A. annua were more effective than other applied concentrations of EOs in reducing the lipid contents of the X. luteola egg cells because there were no significant differences among the used concentrations. 


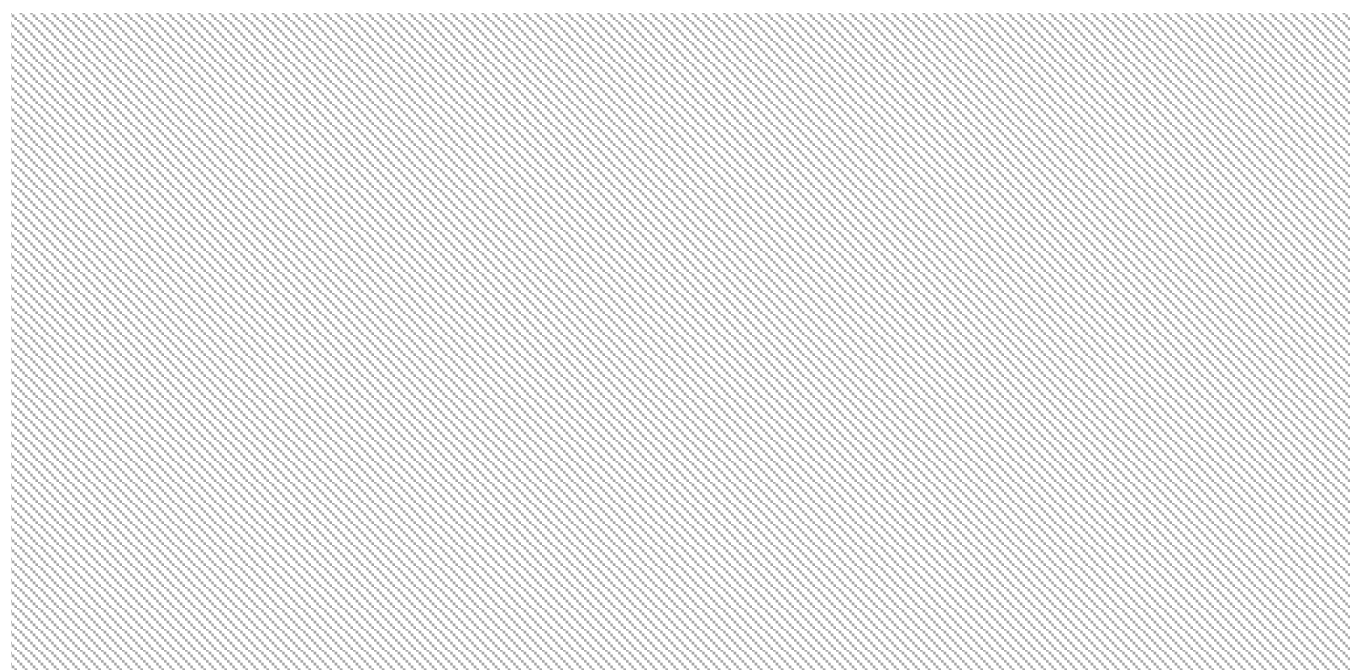

Figure 3. Effect of different concentrations of essential oils on total glucose (mg/dL) of Xanthogaleruca luteola eggs. Statistical differences are shown by different letters according to Tukey's test at $p \leq 0.05$.

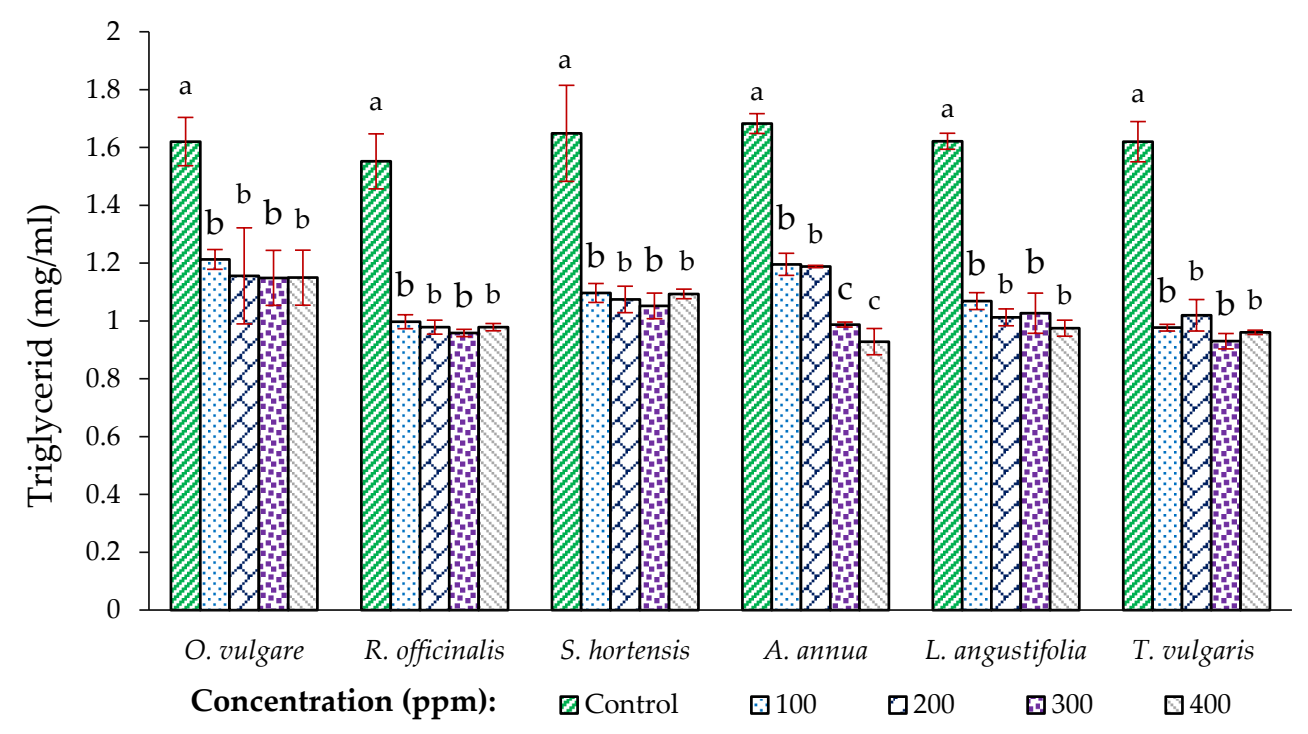

Figure 4. Effect of different concentrations of essential oils on total triglyceride $(\mathrm{mg} / \mathrm{mL})$ of Xanthogaleruca luteola eggs. Statistical differences are shown by different letters according to Tukey's test at $p \leq 0.05$.

\section{Discussion}

The use of plant essential oils to control pests is gaining popularity, as they may provide an eco-friendly alternative to current synthetic insecticides in the control of elm leaf beetle $[1,34,35]$. Different plant EOs including A. annua, Artemisia sieberi Besser, L. angustifolia, Melia azedarach L., Pteridium aquillinum L., and T. vulgaris have previously been studied for their deterrent, toxic, and developmental inhibitory activities against $X$. luteola at the larval stage. The EOs derived from A. annua, A. sieberi [1,36], T. vulgaris, L. angustifolia [34], and R. officinallis [37] have shown repellence, toxicity, biochemical, behavioral, and physiological properties against $X$. luteola. However, the present study offers the first evidence of the ovicidal effect of A. annua, L. angustifolia, O. vulgare, R. officinalis, S. hortensis, and T. vulgaris EOs against $X$. luteola eggs. All applied EOs exhibited a degree of ovicidal activity against $X$. luteola, in which ovicidal activity of T. vulgaris, A. annua, and S. hortensis EOs was promising. Within this study, the difference observed in the level of ovicidal activities for each EO is presumably related to the difference in the accumulation level of active substances in each plant, such as tannic acid, which has embryotoxic effects on insects' eggs and 
larval specifically at high concentration levels [38]. It has been reported that the phenolic compounds of EOs affect the movement and vital systems of the fetus, and they have inhibitory effects on gas exchange inside the egg, which leads to hardening of the crust and direct influence on protoplasm, causing the death of the fetus inside the egg [38]. The ovicidal effects of thyme and lavender against Tetranychus urticae Koch were previously investigated, indicating that lavender oil was the most protective against this spider mite [39]. Bedini [24] reported the oviposition deterrence and toxicity effect of L. angustifolia on adults of common green bottle fly (Lucilia sericata Meigen). In general, many plant EOs have been reported to have an ovicidal effect and high potential to be developed into oviposition deterrent, ovicidal, and adulticidal agents for controlling populations of insects [40-42].

After the treatment of elm leaf beetle eggs with EOs, total protein, glucose, and triglyceride levels declined. Total protein, glucose, and triglyceride are the three required storage macromolecules closely linked with many metabolic pathways. Reduction in the amounts of these macromolecules as a result of insecticidal toxicity can influence several physiological functions such as energy demand, tissue repair, reproduction, etc. Plant EOs can coagulate the cytoplasm and crashed lipids and proteins [43]. Damage to the cell wall and membrane can lead to the leakage of macromolecules and lysis [44]. The result shows that the amount of total protein decreased in the eggs after exposure to different concentrations of EOs. This phenomenon could be due to the breakdown of proteins into free amino acids, which are transferred into Kreb's cycle [45]. The declines that were observed in the amounts of triglyceride and glucose caused by insecticide could also be attributed to an interruption in the absorption system [46].

The results of recent studies on the chemical profile of A. annua, L. angustifolia, O. vulgare, R. officinalis, $S$. hortensis, and T. vulgaris essential oils are reviewed and summarized in Table 3. Terpenes including monoterpene hydrocarbons such as $\alpha$-pinene and $\beta$-pinene, oxygenated monoterpenes such as 1,8-cineole and thymol, and sesquiterpene hydrocarbons such as $\beta$-selinene were the main components of all studied essential oils except $S$. hortensis. Phenylpropanoid compounds estragole and eugenol were the main components of $S$. hortensis essential oil.

Table 3. Main components of the essential oils of Artemisia annua, Lavandula angustifolia, Origanum vulgare, Rosmarinus officinalis, Satureja hortensis, and Thymus vulgaris.

\begin{tabular}{|c|c|c|}
\hline Essential Oil & Main Components (\%) & References \\
\hline A. аппиа & $\begin{array}{c}\text { Camphor }{ }^{\mathrm{OM}}(13.1 \%), \text { artemisia ketone } \mathrm{OM}(11.8 \%), \beta \text {-selinene }{ }^{\mathrm{SH}}(10.7 \%), \\
\text { pinocarvone }^{\mathrm{OM}}(7.4 \%), 1,8 \text {-cineole } \mathrm{OM}(6.8 \%), \alpha \text {-pinene } \mathrm{MH}(5.9 \%) \text {, caryophyllene } \\
\text { oxide }^{\mathrm{OS}}(5.4 \%) \text {, and } \beta \text {-caryophyllene } \\
\mathrm{SH}(3.1 \%)\end{array}$ & [47] \\
\hline L. angustifolia & $\begin{array}{c}\text { Linalool acetate } \mathrm{OM}(35.0 \%) \text {, linalool }{ }^{\mathrm{OM}}(32.7 \%), 1,8 \text {-cineole } \mathrm{OM}(8.1 \%) \text {, camphor } \mathrm{OM} \\
(6.4 \%), \text { borneol } \mathrm{OM}(2.4 \%) \text {, and lavandulyl acetate } \mathrm{OM}(2.0 \%) .\end{array}$ & [48] \\
\hline R. officinalis & 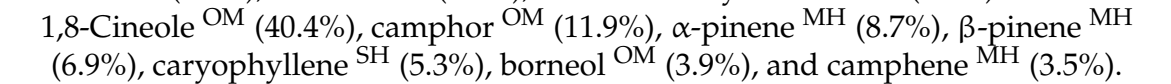 & [48] \\
\hline O. vulgare & $\begin{array}{c}\text { Thymol }^{\mathrm{OM}}(38.8 \%), \gamma \text {-terpinene } \\
\text { (9.5\% }(13.6 \%) \text {, linalool }{ }^{\mathrm{MH}}(13.0 \%), p \text {-cymene }{ }^{\mathrm{MH}}\end{array}$ & [49] \\
\hline S. hortensis & 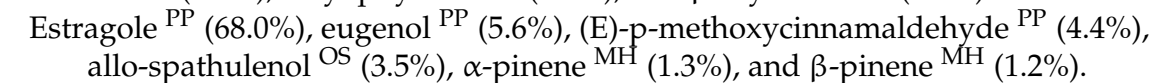 & {$[50]$} \\
\hline T. vulgaris & $\begin{array}{c}\text { Thymol }^{\mathrm{OM}}(38.7 \%), \text { p-cymene }^{\mathrm{MH}}(15.7 \%) \text {, carvacrol }{ }^{\mathrm{OM}}(14.9 \%), \gamma \text {-terpinene } \\
(13.3 \%), \beta \text {-caryophyllene } \\
\mathrm{SH}(2.7 \%) \text {, and 3-carene }{ }^{\mathrm{MH}}(2.2 \%)\end{array}$ & [51] \\
\hline
\end{tabular}

$\mathrm{MH}$ = monoterpene hydrocarbons; $\mathrm{OM}$ = oxygenated monoterpenes; $\mathrm{SH}$ = sesquiterpene hydrocarbons; $\mathrm{OS}$ = oxygenated sesquiterpene; $\mathrm{PP}=$ phenylpropene.

The insecticidal efficiency of plant-derived essential oils has direct interaction with their chemical components. On the other hand, the significant insecticidal effects of main components identified in A. annua, L. angustifolia, O. vulgare, R. officinalis, S. hortensis, and T. vulgaris essential oils were also reported in recent researches. For example, significant toxicity of terpenes thymol and carvacrol and phenylpropene eugenol against larvae of southern house mosquito (Culex quinquefasciatus Say) and adults of the house- 
fly (Musca domestica L.) was reported by Pavela [52]. In the other study, the significant correlation $(p \leq 0.01)$ between 1,8-cineole, camphor, limonene, and $\alpha$-terpinene as major components of T. vulgaris and Mentha spicata L. essential oils and the larval mortality of the Mediterranean flour moth (Ephestia kuehniella Zeller), the carob moth (Ectomyelois ceratoniae Zeller) and the Indian meal moth (Plodia interpunctella Hubner) were found [53]. The acute toxicity and inhibition of the acetylcholine esterase activity of $\alpha$-pinene, $\beta$-pinene, $\beta$-myrcene, 1,8-cineole, $\gamma$-terpinene, $\mathrm{p}$-cymene, linalool, $\beta$-caryophyllene, and caryophyllene oxide against the adults of rice weevil (Sitophilus oryzae (L.)) was approved in the study of Liu et al. [54]. In the other work, the toxicity of 1,8-cineole, p-cymene, $\alpha$-terpinene, $\gamma$-terpinene, $\alpha$-pinene, and $\beta$-pinene, along with essential oils from 24 plant species, was evaluated against adults of the maize weevil (Sitophilus zeamais Motsch) by Patiño-Bayona et al. [55]. They concluded that the essential oils with higher toxicity were branded by a high content of terpenoids and phenylpropanoids. Along with promising insecticidal activity of several introduced components in the present study, including thymol, carvacrol, p-cymene, eugenol, 1,8-cineole, camphor, myrcene, and $\gamma$-terpinene, against the larvae of the tobacco cut-worm (Spodoptera littoralis Boisd.), the synergistic and / or antagonistic effects of some other components such as borneol, linalool, camphene, $\alpha$-pinene, $\beta$-pinene, and limonene was also reported [56]. Accordingly, it can be said that the promising insecticidal effects of $A$. annua, L. angustifolia, O. vulgare, R. officinalis, S. hortensis, and T. vulgaris essential oils may be associated with their insecticide components, especially terpenes and phenylpropenes. It can also be concluded that the more insecticidal properties of T. vulgaris essential oil than the other oils are probably due to the high concentration of pure insecticide components such as thymol, p-cymene, carvacrol, $\gamma$-terpinene, $\beta$-caryophyllene, and 3-carene. However, the synergistic and antagonistic effects of other components in the essential oil should also be considered [56,57].

\section{Conclusions}

Due to their volatile nature and lower residual characteristic of plant EOs, there is a much lower level of risk from EOs to the environment and pollinator insects comparing to current synthetic pesticides [58]. However, some EOs, such as thyme, have an impact on the movement and wax production by pollinator insects such as the western honeybee (Apis mellifera L.) [59]. Therefore, some EOs, such as thyme, should be applied at suitable times (large infestations) and with the concentrations recommended to reduce the inhibitory impacts on the hive. The reactivity of plant EOs depends upon the condition of their growing environment and their composition, which includes different concentrations of aldehydes, phenolics, terpenes, and other natural compounds and the orientation of their functional groups [60]. Further investigations must be undertaken to find the optimal dosage of T. vulgaris, A. annua, and S. hortensis for controlling target insects with the least mortal impacts on non-target organisms and beneficial insects such as hives. This requires further efforts to explore the molecular mechanisms of these essential oils and the effects of their individual chemical compounds on other insects and organisms. The result obtained from the present study indicates that the EOs of T. vulgaris, L. angustifolia, A. annua, S. hortensis, $R$. officinalis, and O. vulgare have ovicidal effects on elm leaf beetle $X$. luteola and an irreversible effect on some key biochemical compounds in this pest. It is expected that plant biorational pesticides will find their greatest commercial application in urban pest control. The ovicidal effects of essential oils reveal that these plants may be a good and safe natural toxicant that warrants further investigation.

Author Contributions: Conceptualization, B.V., M.O., J.J.S. and A.E.; methodology, B.V., J.J.S. and M.O.; formal analysis, B.V., M.O. and A.E.; investigation, B.V., M.O. and A.E.; writing-original draft preparation, B.V., J.J.S., M.O., A.E. and P.K.; writing-review and editing, J.J.S., M.O., A.E. and P.K.; funding acquisition, P.K. All authors have read and agreed to the published version of the manuscript.

Funding: This research received no external funding. 
Data Availability Statement: The data that support the findings of this study are available upon reasonable request.

Acknowledgments: This research was supported by the University of Guilan, which is greatly appreciated. It was also partially supported by Chiang Mai University, Thailand.

Conflicts of Interest: The authors declare no conflict of interest.

\section{References}

1. Chiffelle, Í; Huerta, A.; Bobadilla, V.; Macuada, G.; Araya, J.E.; Curkovic, T.; Ceballos, R. Antifeedant and insecticidal effects of extracts from Melia azedarach fruits and Peumus boldus leaves on Xanthogaleruca luteola larvae. Chil. J. Agric. Res. 2019, 79, 609-615. [CrossRef]

2. Rodrigo, E.; Bosch, A.M.S.; Xamaní, P.; Laborda, R. Life cycle, parasitism and damage of Xanthogaleruca luteola (Mull.) in Valencia (SE Spain): A preliminary study. Urban. For. Urban. Green 2019, 46, 126474. [CrossRef]

3. Moore, G.M.; Lefoe, G. The effect of a heat wave on urban tree pests in Melbourne, Australia: Examples that may inform climate change tree management. Arboric Urban For. 2020, 46, 135-147. [CrossRef]

4. Khater, H.F. Prospects of botanical biopesticides in insect pest management. Pharmacologia 2012, 3, 641-656. [CrossRef]

5. Pavela, R. Essential oils from Foeniculum vulgare Miller as a safe environmental insecticide against the aphid Myzus persicae Sulzer. Environ. Sci. Pollut. Res. 2018, 25, 10904-10910. [CrossRef] [PubMed]

6. Xiong, X.; Yao, M.; Fu, L.; Ma, Z.Q.; Zhang, X. The botanical pesticide derived from Sophora flavescens for controlling insect pests can also improve growth and development of tomato plants. Ind. Crop. Prod. 2016, 92, 13-18. [CrossRef]

7. Plata-Rueda, A.; Martínez, L.C.; Rolim, G.D.S.; Coelho, R.P.; Santos, M.H.; Tavares, W.D.S.; Zanuncio, J.C.; Serrão, J.E. Insecticidal and repellent activities of Cymbopogon citratus (Poaceae) essential oil and its terpenoids (citral and geranyl acetate) against Ulomoides dermestoides. Crop. Prot. 2020, 137, 105299. [CrossRef]

8. Fowsiya, J.; Madhumitha, G.A. Review of bioinsecticidal activity and mode of action of plant derived alkaloids. Res. J. Pharm Technol. 2020, 13, 963-973. [CrossRef]

9. Abad, M.J.; Bedoya, L.M.; Apaza, L.; Bermejo, P. The Artemisia, L. genus: A review of bioactive essential oils. Molecules 2012, 17, 2542-2566. [CrossRef]

10. Ebadollahi, A.; Ziaee, M.; Palla, F. Essential oils extracted from deferent species of the Lamiaceae plant family as prospective bioagents against several detrimental pests. Molecules 2020, 25, 1556. [CrossRef]

11. Isman, M.B. Commercial development of plant essential oils and their constituents as active ingredients in bioinsecticides. Phytochem. Rev. 2020, 19, 235-241. [CrossRef]

12. Domingues, P.M.; Santos, L. Essential oil of pennyroyal (Mentha pulegium): Composition and applications as alternatives to pesticides-New tendencies. Ind. Crops Prod. 2019, 139, 111534. [CrossRef]

13. Yazdani, E.; Jalali Sendi, J.; Aliakbar, A.; Senthil-Nathan, S. Effect of Satureja hortensis L. essential oil on feeding efficiency and biochemical properties of Glyphodes pyloalis Walker (Lepidoptera: Pyralidae). Arch. Phytopathol. Plant. Protect. 2013, 46, 328-339. [CrossRef]

14. Benelli, G.; Pavela, R. Repellence of essential oils and selected compounds against ticks-A systematic review. Acta. Trop. 2018, 179, 47-54. [CrossRef] [PubMed]

15. Papanastasiou, S.A.; Ioannou, C.S.; Papadopoulos, N.T. Oviposition-deterrent effect of linalool-a compound of citrus essential oils-on female Mediterranean fruit flies, Ceratitis capitata (Diptera: Tephritidae). Pest. Manag. Sci. 2020, 86, 3066-3377. [CrossRef]

16. Valizadeh, B.; Zibaee, A.; Jalali Sendi, J. Inhibition of digestive $\alpha$-amylases from Chilo suppressalis Walker (Lepidoptera: Crambidae) by a proteinaceous extract of Citrullus colocynthis L. (Cucurbitaceae). J. Plant. Protec. Res. 2013, 53, 195-202. [CrossRef]

17. Marimuthu, G.; Rajamohan, S.; Mohan, R.; Krishnamoorthy, Y. Larvicidal and ovicidal properties of leaf and seed extracts of Delonix elata (L.) Gamble (Family: Fabaceae) against malaria (Anopheles stephensi Liston) and dengue (Aedes aegypti Linn.) (Diptera: Culicidae) vector mosquitoes. Parasitol. Res. 2012, 111, 65-77. [CrossRef]

18. Isman, M.B. Botanical insecticidal, deterrents, and repellents in modern agriculture and increasingly regulated world. Annu. Rev. Entomol. 2006, 51, 45-66. [CrossRef]

19. Jankowska, M.; Rogalska, J.; Wyszkowska, J.; Stankiewicz, M. Molecular targets for components of essential oils in the insect nervous system-A review. Molecules 2017, 23, 34. [CrossRef]

20. Adibmoradi, G.; Jalali Sendi, J.J.; Tirgari, S.; Imani, S.; Nematolahi, S.R. Insecticidal and morpho-physiological disorders caused by Thymus vulgaris L. essential oil on the elm leaf beetle, Xanthogaleruca luteola Müller (Coleoptera: Chrysomelidae). Arch. Phytopath. Plant. Protect. 2020, 53, 765-780. [CrossRef]

21. Campbell, B.E.; Pereira, R.M.; Koehler, P.G. Complications with Controlling Insect Eggs: Insecticide Resistance, 1st ed.; Intech: Rijeka, Croatia, 2016; pp. 83-96.

22. Amri, I.; Hamrouni, L.; Hanana, M.; Jamoussi, B.; Lebdi, K. Essential oils as biological alternatives to protect date palm (Phoenix dactylifera L.) against Ectomyelois ceratoniae Zeller (Lepidoptera: Pyralidae). Chil. J. Agric. Res. 2014, 74, 273-279. [CrossRef]

23. Naseri, B.; Abedi, Z.; Abdolmaleki, A.; Jafary-Jahed, M.; Borzoui, E.; Mansouri, S.M. Fumigant Toxicity and sublethal effects of Artemisia khorassanica and Artemisia sieberi on sitotroga cerealella (Lepidoptera: Gelechiidae). J. Insect Sci. 2017, 17. [CrossRef] [PubMed] 
24. Bedini, S.; Flamini, G.; Cosci, F.; Ascrizzi, R.; Echeverria, M.C.; Gomez, E.V.; Guidi, L.; Landi, M.; Lucchi, A.; Conti, B. Toxicity and oviposition deterrence of essential oils of Clinopodium nubigenum and Lavandula angustifolia against the myiasis-inducing blowfly Lucilia sericata. PLoS ONE 2019, 14, e0212576. [CrossRef]

25. Regnault-Roger, C.; Vincent, C.; Arnason, J.T. Essential oils in insect control: Low-risk products in a high-stakes world. Annu. Rev. Entomol. 2012, 57, 405-424. [CrossRef] [PubMed]

26. Magierowicz, K.; Górska-Drabik, E.; Sempruch, C. The effect of Tanacetum vulgare essential oil and its main components on some ecological and physiological parameters of Acrobasis advenella (Zinck.) (Lepidoptera: Pyralidae). Pestic. Biochem. Physiol. 2020, 162, 105-112. [CrossRef] [PubMed]

27. Valizadeh, B.; Jalali Sendi, J. Sublethal effects of pyriproxyfen on some biological and biochemical properties of elm leaf beetle, Xanthogaleruca luteola (Col.: Chrysomelidae). J. Entomol. Soc. Iran. 2014, 33, 59-70.

28. British Pharmacopoeia; HMSO: London, UK, 1988; Volume 2, pp. 137-138.

29. Ribeiro, W.L.C.; Camurça-Vasconcelos, A.L.F.; Macedo, I.T.F.; dos Santos, J.M.L.; de Araújo-Filho, J.V.; Ribeiro, J.D.C.; Pereira, V.D.A.; Viana, D.D.A.; de Paula, H.C.B.; Bevilaqua, C.M.L. In vitro effects of Eucalyptus staigeriana nanoemulsion on Haemonchus contortus and toxicity in rodents. Veter. Parasitol. 2015, 212, 444-447. [CrossRef]

30. Lowry, O.H.; Rosebrough, N.J.; Farr, A.L.; Randall, R.J. Protein measurement with the Folin phenol reagent. J. Biol. Chem. 1951, 193, 265-275. [CrossRef]

31. Siegert, K.J. Carbohydrate metabolism in Manduca sexta during late larval development. J. Insect Physiol. 1987, $33,421-427$. [CrossRef]

32. Fossati, P.; Prencipe, L. Serum triglycerides determined colorimetrically with an enzyme that produces hydrogen peroxide. Clin. Chem. 1982, 28, 2077-2080. [CrossRef]

33. Abbott, W.S. A method of computing the effectiveness of an insecticide. J. Econ. Entomol. 1925, 18, 265-267. [CrossRef]

34. Khosravi, R.; Jalali Sendi, J.J. Toxicity, development and physiological effect of Thymus vulgaris and Lavandula angustifolia essential oils on Xanthogaleruca luteola (Coleoptera: Chrysomelidae). J. King Saud Univ. Sci. 2013, 25, 349-355. [CrossRef]

35. Adibmoradi, G.; Sendi, J.J.; Tirgari, S.; Imani, S.; Nematolahi, S.R. Effect of 1,8-cineol on the biology and physiology of elm leaf beetle, Xanthogaleruca luteola (Col.: Chrysomelidae). J. Plant. Protect. Res. 2018, 58, 420-430. [CrossRef]

36. Shekari, M.; Jalali Sendi, J.; Etebari, K.; Zibaee, A.; Shadparvar, A. Effects of Artemisia annua L. (Asteracea) on nutritional physiology and enzyme activities of elm leaf beetle, Xanthogaleruca luteola Mull. (Coleoptera: Chrysomelidae). Pestic. Biochem. Physiol. 2008, 9, 66-74. [CrossRef]

37. Krzyżowski, M.; Baran, B.; Łozowski, B.; Francikowski, J. The effect of Rosmarinus officinalis essential oil fumigation on biochemical behavioral, and physiological parameters of Callosobruchus maculatus. Insects 2020, 11, 344. [CrossRef]

38. Al-Murmidhi, M.M.A.F.; Al-Hasnawi, M.R.A. The toxicity of phenolic compounds to some plants in the cumulative loss of the adult stages of domestic flies. Musca domestica (Diptera: Muscidae). J. Phys. 2019, 1294, 062009. [CrossRef]

39. Modarres-Najafabadi, S.S. Control of Tetranychus urticae Koch by thyme, lavender and eucalyptus essential oils. J. Med. Plants By-Prod. 2012, 1, 43-47. [CrossRef]

40. Gong, X.; Ren, Y. Larvicidal and ovicidal activity of carvacrol, p-cymene, and $\gamma$-terpinene from Origanum vulgare essential oil against the cotton bollworm, Helicoverpa armigera (Hübner). Environ. Sci. Pollut. Res. 2020, 27, 18708-18716. [CrossRef]

41. Cotchakaew, N.; Soonwera, M. Toxicity of several botanical essential oils and their combinations against females of Aedes albopictus (Skuse) and Anopheles minimus (Theobald): Oviposition deterrent, ovicidal and adulticidal efficacies. Asian Pac. J. Trop. Biomed. 2019, 9, 1-29. [CrossRef]

42. Sarma, R.; Adhikari, K.; Mahanta, S. Twenty essential oils as ovicidal agent against Aedes aegypti (Diptera: Culicidae). Natl. Acad. Sci. Lett. 2020, 43, 497-500. [CrossRef]

43. Gustafson, J.E.; Liew, Y.C.; Chew, S.; Markham, J.L.; Bell, H.C.; Wyllie, S.G. Effects of tea tree oil on Escherichia coli. Lett. Appl. Microbiol. 1998, 26, 194-198. [CrossRef] [PubMed]

44. Oussalah, M.; Caillet, S.; Salmieri, S.; Saucier, L.; Lacroix, M. Antimicrobial effects of alginate-based films containing essential oils on Listeria monocytogenes and Salmonella typhimurium present in bologna and ham. J. Food Prot. 2007, 70, 901-908. [CrossRef] [PubMed]

45. Wu, G. Amino Acids: Biochemistry and Nutrition, 2nd ed.; CRC Press: Boca Raton, FL, USA, 2021; pp. 510-545.

46. Etebari, K.; Matindoost, L. A study on the effects of larval age on biochemical macromolecules abundance of haemolymph in silkworm Bombyx mori L. (Lepidoptera: Bombycidae). J. Entomol. Soc. Iran. 2004, 24, 1-16.

47. Oftadeh, M.; Jalali Sendi, J.; Ebadollahi, A.; Setzer, W.N.; Krutmuang, P. Mulberry protection through flowering-stage essential oil of Artemisia annua against the lesser mulberry pyralid, Glyphodes pyloalis Walker. Foods 2021, 10, 210. [CrossRef]

48. Valková, V.; Ďúranová, H.; Galovičová, L.; Vukovic, N.L.; Vukic, M.; Kačániová, M. In Vitro antimicrobial activity of lavender, mint, and rosemary essential oils and the effect of their vapours on growth of Penicillium spp. in a bread model system. Molecules 2021, 26, 3859. [CrossRef]

49. Goyal, S.; Tewari, G.; Pandey, H.K.; Kumari, A. Exploration of productivity, chemical composition, and antioxidant potential of Origanum vulgare L. grown at different geographical locations of Western Himalaya. India J. Chem. 2021, 12. [CrossRef]

50. Ebadollahi, A.; Taghinezhad, E.; Setzer, W.N.; Chen, G. Susceptibility of Tribolium castaneum (Coleoptera: Tenebrionidae) to the fumigation of two essential Satureja oils: Optimization and modeling. Processes 2021, 9, 1243. [CrossRef] 
51. Ed-Dra, A.; Nalbone, L.; Filali, F.R.; Trabelsi, N.; El Majdoub, Y.O.; Bouchrif, B.; Giarratana, F.; Giuffrida, A. Comprehensive evaluation on the use of Thymus vulgaris essential oil as natural additive against different serotypes of Salmonella enterica. Sustainability 2021, 13, 4594. [CrossRef]

52. Pavela, R. Insecticidal properties of phenols on Culex quinquefasciatus Say and Musca domestica L. Parasitol. Res. 2011, 109, 1547-1553. [CrossRef]

53. Aissaoui, F.; Hedjal-Chebheb, M.; Soltani, A.; Haouel-Hamdi, S.; Talhi, O.; Chérif Ziani, B.E.; Mediouni-Ben Jemâa, J. Variations of chemical composition of two Algerian essential oils collected for different seasons and assessment of their insecticidal toxicity against three moth pests. Chem. Rev. 2007, 107, 2411-2502. [CrossRef]

54. Liu, T.-T.; Chao, L.K.-P.; Hong, K.-S.; Huang, Y.-J.; Yang, T.-S. Composition and insecticidal activity of essential oil of Bacopa caroliniana and interactive effects of individual compounds on the activity. Insects 2020, 11, 23. [CrossRef] [PubMed]

55. Patiño-Bayona, W.; Galeano, L.N.; Cortes, J.B.; Ávila, W.D.; Daza, E.H.; Suárez, L.; Prieto-Rodríguez, J.; Patiño-Ladino, O. Effects of Essential Oils from 24 Plant Species on Sitophilus zeamais Motsch (Coleoptera, Curculionidae). Insects 2021, 12, 532. [CrossRef] [PubMed]

56. Pavela, R. Acute, synergistic and antagonistic effects of some aromatic compounds on the Spodoptera littoralis Boisd. (Lep., Noctuidae) larvae. Ind. Crop. Prod. 2014, 60, 247-258. [CrossRef]

57. Pavela, R. Acute toxicity and synergistic and antagonistic effects of the aromatic compounds of some essential oils against Culex quinquefasciatus Say larvae. Parasitol. Res. 2015, 114, 3835-3853. [CrossRef] [PubMed]

58. Campos, E.V.; Proença, P.L.; Oliveira, J.L.; Mansi Bakshi, P.C.; Fraceto, L.F.A. Use of botanical insecticides for sustainable agriculture: Future perspectives. Ecol. Indic. 2019, 105, 483-495. [CrossRef]

59. Carayon, J.-L.; Téné, N.; Bonnafé, E.; Alayrangues, J.; Hotier, L.; Armengaud, C.; Treilhou, M. Thymol as an alternative to pesticides: Persistence and effects of Apilife Var on the phototactic behaviour of the honeybee Apis mellifera. Environ. Sci. Pollut. Res. Int. 2014, 21, 4934-4939. [CrossRef]

60. Swamy, M.K.; Akhtar, M.S.; Sinniah, U.R. Antimicrobial properties of plant essential oils against human pathogens and their mode of action: An updated review. Evid. Based Complement. Alternat. Med. 2016, 2016, 3012462. [CrossRef] 